\title{
ART AND ENTERTAINMENT IN THE NEW ORDER'S JAILS
}

\author{
Hersri \\ Translated and Introduced by Keith Foulcher
}

\section{Introduction}

"Art and Entertainment in the New Order's Jails" is one of three long essays on the experience of political imprisonment in Indonesia's New Order, written between 1991 and 1993 and published by the author from his home in the Netherlands, in the middle of 1993.1 It forms part of a large corpus of writing, including the 276 page manuscript by Pramoedya Ananta Toer, Nyanyian Tunggal Seorang Bisu [The Lone Song of a Mute], which documents the deprivation and suffering of those imprisoned in the wake of the New Order's rise to power in 1965/66. For periods of up to fourteen years, tens of thousands of Indonesians found themselves imprisoned without trial in brutal and inhuman conditions for no other reason than their past membership of organizations having connections to the pre-1965 left, and the political and ideological commitments which association with these organizations was seen to imply.

Hersri Setiawan, the writer of this essay, was at the time of his imprisonment a former member of Lekra, the "People's Cultural Institute" that had connections with the PKI, the Indonesian Communist Party. Between 1958 and 1960, he had held a leadership position in the Central Java office of the organization, before taking up a position as Indonesia's representative at the Asia-Africa Writers' Bureau in Colombo, Sri Lanka, which he held between 1961 and August 1965. He returned to Indonesia on the eve of the coup and counter-coup of September-October 1965, which began the wave of killings and imprisonment directed at Communists and their perceived supporters. Initially avoiding arrest, he worked for the

\footnotetext{
${ }^{1}$ Hersri S., Dunia Yang Belum Sudah [An unfinished world] (Kockengen, 1993). The other two essays in the collection, "Gender dan Narasi" ["Gender and narration"] and "Dua Dunia: Perjalanan dan Penulisan" ["Two worlds: travels and writing"] were written for Writers' Week at the 1993 Perth Festival in Western Australia. "Art and Entertainment in the New Order's Jails," written in 1991, formed the basis of a number of seminars given at various Australian universities, following the author's participation in the Perth Festival.
} 
next four and a half years as a freelance journalist and translator in Jakarta, while at the same time studying International Relations at a Jakarta university. ${ }^{2} \mathrm{He}$ was arrested in December 1969, and spent the following nine years in detention, initially in Jakarta, and then in the internment camp established to house political prisoners on the island of Buru. He was released into the uncertainties of life as an ex-tapol in December 1978, and left Indonesia to make his home in Holland at the end of $1988 .^{3}$

In writing "Art and Entertainment in the New Order's Jails," Hersri appears to have had two principal aims in mind. The first was clearly to document for posterity the range of creative activity which political prisoners, many of whom had been among the country's leading artists and performers, contrived to undertake in prison. "Performances," in his recollections, could be "staged" in the most ingenious of ways. From behind his cell bars, for example, a dalang could summon the aid of singers and musicians locked in surrounding cells for the performance of a wayang play, each of the performers being rewarded with contributions from those who had received parcels from visitors earlier in the day. Later, under the conditions of distorted normality in the Buru camp, theater "buildings" saw the performance of gamelan, and both traditional and modern drama, before audiences of more than 500. A later section of the essay is devoted to documenting the range of written compositions completed by prisoners in Buru, from the novels of Pramoedya Ananta Toer to a range of musical compositions, versions of well-known tales like Pranacitra Rara Mendut, to historical dramas and novels and translations that varied from a guide to acupuncture to Plato's Republic. The documenting of this range of written expression is important to Hersri, as it serves to point out that the towering figure of Pramoedya was surrounded by the creative energies of other, albeit lesser, artists, and that taken together, this "literature of exile" deserves its place as a chapter in the history of modern Indonesian art.

The second of Hersri's aims in writing this memoir is already contained in the first. In his documenting of the creative energy that surfaced amid the extremities of prison life, he is reminding his readers of the resilience of the human spirit, the will not only to survive, but to enrich whatever can be salvaged of the essence of human life, and to savor those moments that recall the full potential and meaning of life. Hersri writes not only of artistic performances and achievement, but much that relates to the conduct of everyday life, prison "culture" in the broad sense, and his own asides on this narrative are often underpinned by a humanism that survives the conditions imposed on prisoners by their jailers. His forthright dismissal of the views of those "moralistic Communists" who condemned the prevalence of homosexual relationships among a surprising number of prisoners is a remarkable case in point. Hersri himself finds both "immorality" and the satisfaction of the "biological urge" equally inadequate explanations of the institution of "pertandakan" in the Buru camp. He prefers to see prisoners involved in homosexual relationships as led rather by the human urge to love and be loved, and the longing for freedom, the freedom to whisper one's complaints and dreams to a fellow human being.

The humanism implicit in Hersri's essay recalls the humanist values which underlay both of the opposing cultural-political camps which divided Indonesian cultural life in the first half of the 1960s, and which ultimately led to the story of human tragedy which the essay recounts. Although both the "left" and the "right" of the cultural-political divide of

\footnotetext{
${ }^{2}$ See David T. Hill, "Editor's Introduction" in Ruth Havelaar, Quartering, A Story of a Marriage in Indonesia during the Eighties (Clayton, Monash Papers on Southeast Asia No. 24, 1991), pp. xiii-xvi.

${ }^{3}$ Ibid., pp. xxiii-xxiv. The story of Hersri's life after his release from prison, and the cirumstances of his move to Holland, are movingly related in Havelaar's memoir.
} 
this period saw each other's politics and the practices that flowed from political commitments as the enemy, they were both motivated by a similar humanist conception of art as the expression of the human spirit in its purest form, with the potential to transcend and perfect the day-to-day problems of actual social relations. When Hersri writes "however cruelly a system of power oppresses creative freedom, it can never destroy the artist and the work of art," he shows his common intellectual heritage with the writers of the Cultural Manifesto of 1963, who sought in their own formulation at that time to make a similar statement in regard to what they perceived as the domination of art by politics in Sukarno's Indonesia. Tragically, as this aspect of Hersri's essay reminds us, there was always a great deal that artists and intellectuals of both camps held in common during those years. An essential humanism was among the values and commitments they shared.

One further aspect of Hersri's memoirs should be mentioned here. There is a sense in which "Art and Entertainment in the New Order's Jails" records the latest episode in what is an ongoing story of one aspect of political life in modern Indonesia:

Besides gamelan performances, from time to time the exiles organised other entertainments, such as the performance of classical and folk dances, displays of the Indonesian system of self-defence that is called pencak silat, and once or twice, even slapstick comedy. Bondan himself sometimes played the violin....4

Wayang orang, traditional Javanese dance-theater, was performed in the camp. The Digoel Concert Band-nicknamed Digoel Bu-sneert, "Digul Trash-Can," by the internees-played its own version of jazz. At one time or other, there were at the camp the Opera Association Orient and the Music and Opera Association Liberty (both names were in English) and they played komedie stambul, the Malay theatrical genre full of sweet songs and romantic action which ... had been such a craze in Medan during the 1910s and 1920s. ... The camp cinema in Tanah Merah featured Tarzan, Tom Mix and Douglas Fairbanks. ... 5

Both these extracts, of course, are from recently published descriptions of life in that other infamous internment camp of modern Indonesian history, established by the Dutch colonial government on the upper reaches of the Digul river in the eastern part of Irian Jaya, formerly Dutch New Guinea, in the late 1920s. Tanah Merah, and its outpost Tanah Tinggi, as this camp was called, was established to house radical nationalist intellectuals and activists in the climate of repression that followed the abortive Communist uprisings in the Netherlands Indies in 1926/27. Just as was the case with the Buru camp of the 1970s, Tanah Merah was home to some of Indonesia's most prominent intellectuals and politicians of the time, including, for a period, Hatta and Sjahrir. Its inmates faced a degree of isolation and deprivation, along with the ravages of disease, climate, and a hostile local population, that took the lives of many of the educated elite of the time. Yet as the above extracts indicate, a culture of exile took shape too in Digul, no less vigorous than that which Hersri describes as existing in Buru, and no less a testimony to the courage and resilience of those Indonesians

\footnotetext{
${ }^{4}$ Molly Bondan, Spanning a Revolution! The Story of Mohamad Bondan and the Indonesian Nationalist Movement (Jakarta: Sinar Harapan, 1992), p. 160.

${ }^{5}$ Rudolf Mrazek, Sjahrir, Politics and Exile in Indonesia, Studies on Southeast Asia, No. 14 (Ithaca: Cornell University Southeast Asia Program, 1994), p. 134.
} 
who suffered unimaginably for the cause of the Indonesian state they believed in and were committed to working for, at both points in the modern history of the nation.

There is, however, one aspect of Hersri's description of the prison culture of Buru that one finds no mention of in the accounts of the experiences of the inmates of Tanah Merah. However great was the suffering occasioned by isolation, deprivation, and disease in Tanah Merah, we find nothing comparable in these accounts to Hersri's record of the acts of wanton cruelty and brutality perpetrated on the prisoners of Buru by their military captors. Hersri's description of the pummeling of the stomach of a prisoner complaining of stomach pains until this "free medicine" had worked its wonders, or the "anti-malarial treatment" that forced a prisoner complaining of fever to run around a field until he "no longer felt cold," give this account an element that strikes the reader as all the more obscene for being the documentation of cruelty suffered not in the name of anti-colonialism, but by some Indonesians at the hands of others. The suffering endured by the Digulists in the fight for a free Indonesia was tragically not the end of the story. As recently as the 1970s, internal exile and its attendant inhumanity were still a part of modern Indonesian political history.

\section{A note on the translation}

The original Indonesian version of this essay is richly "literary" in its use of language and allusion, qualities which the translation fails to reproduce. I have aimed at a style of translation that makes the essay fluent and readable, and for this reason I have chosen not to use footnotes or excessive glossing of Indonesian terminology. Information footnoted in the original text has been incorporated into the body of the translation, as have a number of

clarifications and explanations provided to me by the author. I am assuming that readers of the translation will have some familiarity with Indonesian culture, and as such may be spared the irritant of the over-zealous glossing of familiar terminology and historical references that sometimes mar the reading of texts such as this one. 


\title{
ART AND ENTERTAINMENT IN THE NEW ORDER'S JAILS
}

\author{
Hersri
}

\section{Salemba}

\section{Watching Goats Mating}

In the middle of Salemba prison lies an assembly yard. It is there that Muslim political prisoners performed their obligatory Friday prayers and other religious observances, and where flag-raising ceremonies were held on Independence Day, and other national days such as Heroes' Day and Sacred Pancasila Day.

But apart from these political and ideological "observances," the assembly yard was also the site for the obligatory afternoon recreation period-handball and volleyball for those prisoners not in isolation who were summoned to take part. When it was not being used, this same green field of half a hectare or more was where the goats belonging to the prison officials perpetuated their kind: grazing, suckling their young, fighting, and mating. Male goats apparently mate all year round, unlike cats or dogs, for instance. So it's appropriate that Malay has an expression for a man who is always looking for a woman, "just like an old billy goat." (Even though one of S. Sudjojono's best paintings is called "It's a Pity I'm not a Dog," rather than "It's a Pity I'm not a Goat.")

In the late afternoon, waiting for the ration of water and the second and final daily meal, the cell doors were sometimes opened and the prisoners allowed to "have fun" in the yard around the cellblock. Each of the prisoners had his own way of making use of this valuable opportunity: taking deep breaths of fresh air, warming the blood by walking quickly around the yard, looking for cigarette butts and collecting the leftover tobacco, looking for bones or coconut shells to make into pipes for smoking, for bits of discarded plastic to twist and weave into bags. And there were some who crowded around the $75 \mathrm{~cm}$ barred opening in the locked gate to the yard: watching the goats mating.

Whether it was the work of prisoners on kitchen duty looking for something to do, or whether it was on the order of the prison officials, one day all the female goats appeared "dressed" in bits of old sackcloth. It may have been intended as a kind of "ban" stopping 
the goats from mating, so the prisoners wouldn't crowd around the cellblock gates cheering them on. But it had precisely the opposite effect: subjecting the male goats to enforced "family planning" made them that much more aggressive toward the females. And the prisoners, who had spent years of enforced abstinence from all forms of physical passion, roared all the more in their laughter.

It was a tragic comedy, not just for the goats, but also for the prisoners. The goats here had served to awaken basic human instincts, and to remind a group of humans of their humanity. This was the second time goats had provided such a lesson for human beings. The first time this occurred is recorded in a part of a manuscript by Mangkunegara IV, one of the rulers of the court of Surakarta, and in the oral tales concerning Prabu Anglingdarma. There we find the story of the goat which taught a lesson to Prabu Anglingdarma on top of the cremation pyre in the alun-alun of Malwapati. The prince, with his magical knowledge of the language of animals, was about to sacrifice himself beside his princess, Dewi Setyawati, who was committing herself to the flames because of his refusal to share this secret knowledge with her. A pair of goats happened on the scene. The female goat asked her mate, "Would you die in company with me, like Prabu Anglingdarma with his beloved?" "No way," the male goat replied, "Let those who live continue to live. Anglingdarma has lost sight of his own life and death." Hearing the goat's words, Anglingdarma left the princess to die alone, rather than renounce his own life's course. Like the prisoners of Salemba, Prabu Anglingdarma was reminded by the goats that the will to go on living, the life force, must not be denied, whatever our circumstances may be.

\section{Wayang Kandha and the Plastic Orchestra}

Three days a week, on visiting days, the families of the political prisoners were allowed to bring parcels. The prisoners were allowed to receive anything the families brought, except forbidden goods, like sharp implements (including nail files), matches, reading mate-

rial, writing implements (including cigarette papers) and anything that was recreational or could be considered an instrument for communication. For this reason, everything the visitors brought had to be passed through an inspection window. The prison officers inspected everything in the visitors' bags one at a time (even rice, vegetables, and cigarettes were mixed up and pulled apart), and subjected it all to a "levy" according to their needs and tastes, before sending it on to the particular prisoner's cellblock. There the block officers would impose their own levy, according to the same principles, before not infrequently passing on nothing more than an empty bag to the prisoner! This same "levy practice" was known to the political prisoners jailed after the "Madiun Affair" of 1948. It led to a new meaning being given to the "KMK" (Komando Militer Kota-City Military Command). For the prisoners, "KMK" came to stand for "Kumpulan Maling dan Kecu" ("Thieves and Robbers' Club").

This was the unofficial levy. Subsequently, after visiting hours, when the prisoner was about to share the enjoyment of his package with his cellmates, two or three block officers would come with plastic buckets to collect the "official levy." It was their job to collect "alms" for those prisoners who for various reasons never received packages of their own.

Creativity and recreation don't always depend on having the right equipment. Neither do they always have to be brought together in the same space. In the prison, recreation activities could be orchestrated between cells separated from one another. In the late afternoon, after the visiting hour (and, of course, taking into account the security situation) the prisoners in particular cells would sometimes hold "entertainment nights" or "performance nights." 
Isya, or evening prayer, is the last in the series of five Islamic daily prayers, and as such it marked the division between day and night, and one day and the next, in jail. The soldiers on guard duty would from this point spend more time at their posts, in the watchtowers or right out in front of the prison. And for the prisoners in the block where the activity was to be held, this was the moment to begin.

If there was to be a wayang performance, the dalang would stand up in his cell, and hanging on the bars of the door, would call on his comrades in the other cells for their assistance: the players of the instruments (gending, kendang, and gong) and the singers (pesinden and penggerong). Then he would announce the play to be performed, followed by a second call, this time directed at those who had just received parcels from visitors, asking them to make voluntary honoraria to those who were making the performance possible. Plastic parcels of sugar, palm sugar, cassava, sweet potato, and tobacco would then be thrown from various directions toward the dalang's cell. He would then distribute the contributions by throwing them toward the cells of his assistants.

Usually the play would be taken from the wayang carangan repertoire, or from one of the standard lakon; in either case it would be a story of bravery and heroism (such as Senggono Obong, Gatutkaca Gugur, Kikis Tunggarana), of temporary victory through deceit (Kresna Kembar, Pendhawa Dhadhu) or confusions that resulted from role reversals (Prabu Belgedhuwelbeh or Petruk Jadi Raja). If it was to be a musical performance, the process was the same. The main instruments were plastic buckets, so it was called the "plastic orchestra." (This was to suggest a link with the "bamboo orchestra" of the years of national revolution, that consisted mainly of beaten, plucked, and blown instruments made of bamboo.) The initiator would seek out players, allot the parts, call on the others to come up with donations, and distribute the donations to the players. The difference between the two types of performance was that whereas the wayang depended solely on oral performance, the musical events (other than the singing) employed all kinds of "instruments": tin bowls and spoons, brooms and cell floors, wooden sticks and the cell bars, and the plastic buckets, both with "strings" of belts, and without.

The music performed, in order of preference, consisted of kroncong (including langgam kroncong), dangdut (though at that time, dangdut consisted of two separate genres more commonly known as "Irama Padang Pasir" and "Irama Melayu"), and a few popular songs. Songs composed for choir (mostly what Bung Karno called "booming rhythm") were never performed, probably for reasons of "political caution," to avoid accusations of "stubborn revolutionary attitudes." The anthems Rayuan Pulau Kelapa by Ismail Mz. and Nyiur Hijau by Maladi were usually performed as the concluding items. "Lieder"-type music, such as Kemuning, with words by Sanusi Pane, to music of Cornel Simandjuntak or Lagu Biasa, with words by Chairil Anwar, to music of Amir Pasaribu, were almost never heard at all, an indication that the work of the PKI and progressive cultural organizations (mainly Lekra, but also to some extent LKN) in the field of music was not comprehensive, even though Nyoto continually emphasized to Lekra artists and writers the need to "know everything about something and something about everything." Or was it that this type of singing was regarded as elitist and therefore could be ignored? This may have been the case, although one of Nyoto's own poems, written under the pseudonym of Iramani and dedicated to Patrice Lumumba, Merah Kesumba (1961), was set to music in this form by Amir Pasaribu.

\section{"Oral Literature"}

As for "oral literature," there was never any exchange of pantun heard in prison, except in the form of lyrics of Malay songs in the style of P. Ramlee, a well-known star of the silver 
screen in the Malayan Peninsula in the 1950s. There was indeed declamation of poetry, if recitation of verses from the Koran can be counted as such. But free verse was something the prisoners felt remote from, and they would sometimes make fun of the theatrical style of declamation of modern poetry, with made-up examples like "Aku merana/Engkau merene," a play on the Javanese words for "going there" ("mrana") and "coming here" ("mrene"), declaimed theatrically as a line of poetry meaning "I'm going there, and you're coming here." Another example of satirizing modern poetry was the declaiming of two famous lines by Hr. Bandaharo, "No-one will withdraw, though death may lie in wait," as an expression of disappointment at the lack of militancy among Communist cadres.

In contrast to the cynicism with which they viewed modern Indonesian poetry, even the non-Javanese prisoners were well disposed to Javanese macapat songs (especially those in the cengkok semarangan style) and modern Javanese songs (like those of Nartosabdo and Tjokrowasito). There are a number of reasons why this may have been so: the simple rhythms made them easy to imitate and remember, the tunes were soothing and peaceful, the content was usually politically "clean," and in the case of the "empty" popular songs, it was probably precisely the absence of content that made them attractive to prisoners whose general level of art appreciation was zero.

There were not many story tellers, in comparison to the potential audience. At a later stage, when conditions permitted, such as in Buru, where prisoners were able to slip from one barracks to another, it would be possible to see story tellers, after the afternoon assembly, moving around in turn from one barracks to another to deliver their repertoire. Most of the stories they knew came from the type of literature called "pop" or "cheap" literature (either stories by well-known writers like Motinggo Busje, Marga T., and others, or else spontaneous compositions of their own). They also told martial arts (silat) and pseudohistorical stories (like Nagra Sasra Sabuk Inten by S.H. Mintardja, Bende Mataram by Herman Pratikto, Chinese stories like Sam Kok or The Three Kingdoms, and folk legends like Pranacitra Rara Mendut, Sampek Eng Tay, Sangkuriang, and such tales. The repertoire of modern novels was limited to prewar classics like Layar Terkembang by Takdir Alisjahbana and Sitti Nurbaya by Marah Rusli, told by prisoners from the "postwar generation." The "prewar generation" of story tellers had a much wider repertoire of modern Javanese novels, even though most of them were also taken from prewar Balai Pustaka novels like Serat Riyanta by R. Sularto, Ngulandara by Margana Jayaatmaja, Kerti Njunjung Drajat or Ni Wungkuk ing Bendha Growong by Yasawidagda. Apart from perhaps reflecting an alienation from the products of modern Indonesian literature, this may also be an indication of the politics and methods in the teaching of literature in each "generation," as well as the relationship between the schools and Balai Pustaka as the government printer in both the colonial and independence periods.

This doesn't mean, however, that there was no attention given to modern prose in the prison cells. We need only think of the well-known tetralogy by Pramoedya Ananta Toer that was first conceived in oral form among the ricefields of Buru. There were other stories by Pramoedya as well, such as "Wiranggaleng," "Mata Pusaran," and "Arus Balik"), that all circulated quickly and widely in typed form among the units. The late Saleh Iskandar Poeradisastra (Boejoeng Saleh) composed a version of "Pranacitra Rara Mendut," and a novel called "Under the Firing Squad," written and recited in English, in the security interests of those involved. But where modern prose was successful, it was probably the reputation of the story teller rather than the prisoners' appreciation of literature itself that broke down the alienation from modern literature. Moreover, this only happened after the establishment of the Buru penal colony, not before. 


\section{Jailangkung as a Spiritual Consultant}

Not all the cellblocks in the Salemba prison were able to engage in entertainment activities and artistic performances. The distance of a particular block from the guard post and the attitude of the supervisors in that particular block very much determined what was possible. Although the supervisors were all prisoners themselves (except in Block E, which contained military criminal prisoners), there were some blocks where the application of prohibitions was so strict that even talking loudly (without any indication of what was "too" loud) or laughing could be seen as "making trouble." Laughing, whether out loud or not, could be considered as belonging to this category, because it could be interpreted as making fun of those upholding the rules, and for that reason it went down on the list of prohibited actions.

In blocks that were strict about the prohibitions, the toilet was not only the place to relieve yourself, but also the place where once a day you could let out a laugh, which along with its partner, tears, is the primary and basic expression of the life instinct. As such, for prisoners in blocks like this, the allocation of sixty minutes each morning for bathing and going to the toilet was an occasion of great beauty, when they could cheer themselves up and express their most unadulterated thoughts and emotions.

But people (political prisoners included!) don't find art and entertainment a sufficient outlet for fantasy. As such, the prisoners sought ways to break through the prohibitions and physical isolation in order to survive in the world of everyday reality. Listening to the radio and writing letters were easily monitored and traced, and so added to the tension. In fact tension was like the beat of their hearts for the prisoners. So whenever they were able, however infrequently and momentarily, they would ease the tension in simple, relaxed conversation about anything and everything: from trivial pieces of family news, to what their futures might hold, power conflicts in Jakarta, the conflict of the superpowers, anything at all! All this happened not in the form of dialogue with other prisoners, however, but through communication with the spirits of the dead, called jailangkung (or jailangse, if the spirit summoned was a woman). The prisoners were able to express their thoughts and feelings to the spirits without fear of reprisal. And that is what they did, late at night in the corners of the dark and quiet cellblocks.

The jailangkung are what is known as the nini thowong or tini thowok in Javanese tradition. Originally it was a form of animistic ritual, then it developed into a village children's theatrical game during the full moon. But for some reason, when this game re-appeared like a plague in urban areas at the beginning of the 1950s, it was more Chinese than Javanese in form. This may have been because in the Javanese peasant tradition, the spirits were always female, appearing as a Nini (grandmother), whereas the Chinese tradition recognized male and female spirits, and as such it was more easily related to the Javanese concepts of ruler and subject. (In the 1950s version, the male spirits, jailangkung, were in fact more dominant than the female jailangse.) Similarly, in the (male) prisons of Salemba and Tangerang, it was the tradition of the dominant position of the Chinese male, or that of the ruler and ruled, that was followed. I don't know whether the game was popular in women's prisons as well, and whether they too tended to follow the Chinese, masculine model.

Whether what the spirits spoke would turn out to be true in the future was something for the future itself. For now, at least, there was someone to listen to their complaints and answer their questions. It meant they could go to sleep in peace, and face tomorrow with a smile. 


\section{The Island of Buru}

\section{Buru as an Antithesis}

The Indonesian term for the detention center on the island of Buru, tempat pemanfaatan (tefaat) tapol ("a site for making the best use of political prisoners") indicates that it was intended as a penal colony. If life in prison meant incarceration in a cell for the prisoners, here in this prison, they were "set free" amidst the wilds of nature. The consequences could be fatal. For example, one afternoon in 1977, five prisoners in Unit XV and one of the local people who was at the unit's hospital for treatment were struck dead by a bolt of lightning. The appendix to Pramoedya Ananta Toer's Nyanyian Seorang Bisu lists the number of prisoners who fell victim to the harshness of nature in Buru. Despite the dangers, however, and although this was freedom under the watchful eye of the gun, as a penal colony Buru gave the prisoners more room to move in the expression of their creativity.

In New Order Indonesia the political prisoners performed a role analogous to civilization's slaves throughout history. Monuments built by slaves, like Borobudur in Java, the Great Wall in China, and the pyramids of Egypt, are all monuments to the rape of humanity, even though they may also be testimonies to the glory and beauty of civilizations across history.

\section{You created the night and I made the lamp \\ You created clay, and I made the pottery \\ You created the deserts, the mountains and jungles \\ And I produced the ricefields, the gardens and orchards \\ It was I who turned rock into mirrors \\ And poison into cures}

What Iqbal says here is true: the human capacity for creation and innovation is extraordinary, when the circumstances permit.

In the Salemba prison, using discarded materials and stones as tools, the prisoners were able to make all kinds of things: stoves from milk tins, acupuncture needles from spoons, pipes from bones and coconut shells, razors from pieces of glass, brightly colored embroidered goods from pieces of rag. They also devised an ingenious way of communicating with the outside world, by reviving the ancient art of inscribing palm leaf manuscripts. They would wash thoroughly bits of old plastic bag, then cut them into pieces equivalent to about the width of three fingers with a sharp piece of bamboo. Then with a sharp-pointed instrument like a needle or a sharp palm frond, they would write on the sheets of plastic by holding them against the wall of the cell. These little pieces of plastic manuscript would then be twisted into a piece of cord, to tie a label to the bags carried in and out by visitors.

As mentioned above, the opportunities for creative activity were expanded on Buru. As a result, even in the first few months, you could hear the sound of flutes, of zithers, violins, and guitars. You could find things made of woven bamboo or pandanus leaves, and wood carvings. There were dozens of hectares of paddy and dry fields, and just as much land cultivated as productive gardens, all of it hidden from the eyes of the authorities.

All of this was achieved in the gaps left in the sharp and cruel surveillance practiced by the authorities, and by taking advantage of the very limited opportunities afforded by the thirty to sixty minute daily rest periods. Later on, when the colony was around five years old, the use of political prisoner labor became more sophisticated, and this meant that the prisoners had more flexibility in their routine. This gave them more room to move, and they 
devised a number of innovations and improvements in their work equipment, like rice hullers, blowers (hand or pedal driven fans for use in refinement of the rice), implements for removing kernels from ears of corn, bamboo pipes, and carts for transporting goods. On the one hand, it was a natural demand in the interests of survival, but on the other, efficiency of production meant intensified oppression, and for the prisoners, that was like digging their own graves.

\section{Art and Entertainment as an Aspect of Exploitation}

All the units in the Buru penal colony, except the isolation unit Jiku Kecil which was moved in 1974 and given the new name Ancol Unit, had a theater, complete with a stage and benches to seat an audience of more than 500 . They each had two sets of Javanese gamelan (slendro and pelog), and backdrops for performances of modern and traditional drama, made from a kind of hessian obtained from sacks for fertilizer. All of it was the work of the prisoners themselves, in most cases completed in the first year of each unit's existence. Wayang kulit performances were first held in Unit IV/Savanajaya, before they were moved to the command headquarters, after the dalang Tristuti Rachmadi, who was the winner of the award for Indonesia's best dalang for 1964, was himself transferred. The command headquarters was also the only place in the camp that had a full set of instruments to make up a band. In the units themselves the few instruments that existed were the work and the possession of individual prisoners, enough to form kroncong groups or the irama melayu/padang pasir groups that were the forerunners of dangdut.

In 1973, on the occasion of the completion of Colonel AS Rangkuti's term of duty as Commander of the Buru penal colony, the command formed a music group called the command band, under the direction of Basuki Effendi and Subronto K. Atmodjo. When the next commander, Colonel Samsi MS, took up office, this "grouping" of prisoners according to areas of "expertise" was extended and standardized, by placing these professional groups in barracks inside the command headquarters. There was the "engineers' group" who looked after the administration of the command, who numbered among them a few agricultural and civil engineers, the "crew group" who ran the command's three motorized boats, the "Javanese arts group," under the direction of the dalang Tristuti Rachmadi, and the "artists' group", which comprised among others Permadi Lyosta (from Hendra Gunawan's studio Pelukis Rakyat), Sumardjo (from the Seniman Indonesia Muda studio established by Affandi and S. Sudjojono), and Gultom (from the Bumi Tarung studio established by Amrus Natalsja). There was also a craftsmen's group, who were responsible for carving the equipment used in gamelan and wayang performances. It was around that time too that Pramoedya Ananta Toer was separated from his fellow prisoners in the unit and given his own room, first in the theater building and then in the command headquarters complex, after it was moved from Namlea to the banks of the Wai Apo River between Unit I and Unit II. His job there was to write. (One of the prisoners who worked as a coordinator in Unit I, Ibnu BA, suggested that a writers' group be formed in line with the other professional groups, but this suggestion was never taken up.)

Colonel Samsi MS was clever. He turned the "military culture" of the colony into a "slave culture," which though in practice may have appeared to give the prisoners more freedom of expression, was essentially an even harsher form of exploitation. For example, his attitude to roll call was that it was there to count the size of the labor force, in this case, the body of political prisoners in the camp. For that reason, he didn't believe in having the prisoners line up and be counted in military fashion. In his view, the system of "bell counts" or "cattle counts" was sufficient. Prisoners would be lined up one behind the other in five 
"pens," separated by bamboo partitions. As each group of five got to the end of their pens, a bell would be rung and a mark made on a blackboard, before they continued to their places of work. This was time-saving and more efficient, getting the prisoners to their workplaces faster-which was precisely the reason the prisoners had been brought there in the first place. It also avoided the problem of prisoners being beaten for failing to line up properly in military fashion, something they had no experience or knowledge of. If they were beaten, they could be injured and have to spend time in hospital, which took them away from their work. That meant a threat to the efficiency of the work schedule, and if this happened, who but the camp commander would bear the responsibility?

\section{Tug of War with Art and Entertainment}

At certain times, the Javanese arts group and the camp band were ordered to put on a performance in command headquarters. Once every two or three weeks, they would be instructed to do a tour of the units, to entertain the officers and the prisoners. The theme of the performance was predetermined, and a summary (balungan) of the wayang play to be performed had to be submitted far in advance to Command Intelligence. The same applied to the words of any songs to be performed. It was for that reason that some of the prisoners viewed such artistic and entertainment events as useless and even treacherous activities. Useless, because at the most all that could be expected from them was entertainment, and treacherous, because entertainment for the prisoners was just a way of deceiving themselves about the reality of their situation. Entertainment activities inside the camp, so they concluded, were nothing more than an act of servitude to the enemy.

This kind of logic reminded me of Exodus, Leon M Uris's novel of 1958. In the novel, Uris describes the way the Jews filled in their "free time" in the Nazi camps. For example, they would engage in theatrical activities under the umbrella of military training, conduct singing exercises as ideological education, and other sorts of conspiratorial activities. But, I would argue with myself, the reality of a novel may well be far removed from concrete reality, precisely because of the principle of freedom of expression.

The prisoners had a number of terms in their own argot to describe work associated with these performances, all of them referring to some form of "forced labor" (korve). For example, there was "barbed wire korve" for playing music, because the stringed instruments all used barbed wire for their strings; "eye korve" meant watching the performances; "clapping korve" was another term, because every item had to be applauded. The use of "korve" in all this terminology was a clear indication that they saw it as required work outside of work hours (and unpaid, of course), and that they were aware of the absence of any freedom of choice.

But whatever the results were like from the point of view of art or entertainment, these activities were not without benefit for the artists and performers involved. They represented an opportunity to maintain, even develop, their technical skills. And however cruelly a system of power oppresses creative freedom, it can never destroy the artist and the work of art. The form of the work and the way it is created can be the subject of oppression, but not the content and process of creativity.

Art is not born only in the glow of the palace and the church. It can just as well come into being in the darkness of oppression. Didn't some of Indonesia's greatest modern artists appear from under the boot heels of Japanese militarism, at the height of the cruelties of the Second World War? People like the poet Chairil Anwar, the pioneer of modern Indonesian music Cornel Simandjuntak, and of modern Indonesian cinematography Dr Huyung, were 
all products of this period. (The cinematographer Dr Huyung was a former JapaneseKorean military officer, who remained in Indonesia and took Indonesian citizenship after the war. Together with Iskad, he was the founder, in 1948, of the film and drama academy that in Yogyakarta was represented by the Atelier Cinodrama. His most famous films were Between Heaven and Earth [also known as Frieda] [1950?], dealing with the issue of racial prejudice between the "natives" and "Indo Europeans." The song Kemuning by Sanusi Pane and Cornel Simandjuntak was used as musical accompaniment in the second of these films.) Didn't that period of chaos and destruction recall the fate of wayang beber performance art, which was revived as a means of propaganda during the Japanese Occupation and in its turn inspired the nationalist wayang suluh, wayang revolusi, and wayang pancasila, and the Catholic wayang wahyu, among other new and creative developments?

Apart from those prisoners who opposed these performances on ideological and political grounds, there were also those who had moral objections. The existence of performance activities opened up fertile ground for the development of tandak. "Tandak" refers to the institution of the dancing girl, also known as (ta)ledhek, and ronggeng. But the term took on a new meaning in prison life. Linked to the idea of female roles in performances, both those played by men (as in the coastal Javanese ludruk) and by women (as in the lenong plays of the Jakarta area), the term came to refer specifically to those involved in homosexual relations. In the eyes of those "moralistic Communists" who regarded themselves as "supermen," this form of institutionalized homosexuality was regarded as "criminal morality."(!) They claimed further, and there was some truth in this, that homosexual relationships would result in fights, stabbings, and a thousand and one other evils between prisoners, which would turn the basic contradictions between prisoners and the authorities into nonbasic contradictions between the prisoners themselves.

What these "moralistic Communists" paid too little attention to was the widespread incidence of this phenomenon, and the complexity of the factors which produced it. There was one unit of 450 prisoners with a similar frequency of entertainment performances as the other units, that contained seventy tandak. The commandant of another unit formed a company of "Unity and Diversity Maidens," while the commandant or his deputy in several units "kept" tandak prisoners in their quarters. There were other unit commandants, who together with women from the local population (in Units XIV and III there was a certain Ibu Fatimah) opened up brothels around the units. Finally, and this is more important, the tandak didn't just appear in Buru, but were already in existence while the prisoners were incarcerated day and night in their camps in Java. (One informant, Ali Basjah, provided the information that in the Tangerang camp, this form of institutionalized homosexuality was one aspect of illegal party activity that was established within the camp. There were various cadre levels in the organization, each with its own facilities. A party member at one of these levels was able to take a tandak to live with him in his cell.)

In short, incarceration itself wasn't the cause of this expression of homosexuality, nor should it be seen simply as an aspect of "criminal morality." In my view, the existence of homosexual activity in prison (or in a penal colony like Buru) is not primarily brought about by some primordial desire for survival of the species, but should be seen rather as the expression of other basic instincts, both the need of the human being (the biological animal) to love and be loved, and the longing of the person (the political animal) for freedom, the freedom to whisper one's dreams and sorrows to a fellow human being.

The prisoners in Buru described their fellow prisoners who were involved in homosexual activity as suffering from "eye disease" (note the term "disease"!), implying that they were unable to distinguish between male and female. The negativity of this term, the most 
common designation used, is an indication of how pervasive the views of the moralists were. These views were then given political and ideological legitimacy through the interference of a system of military power which exploited the despair felt by those prisoners who viewed the situation in this way.

The influence of the military culture wasn't confined to the prisoners in each of the units, but spread also among the local inhabitants. At first one of their favorite games was trying to spear a piece of fruit hanging by a cord or rolling along the ground, but this game gradually gave way to war games, with bamboo or wooden guns. The soldiers and commanders became the reference points in their dreams of the future. (I have described this phenomenon in more detail in "Pendewasaan di Pulau Buru" in Perjalanan Anak Bangsa (Jakarta: LP3ES, 1982, pp. 296-300))

\section{A Weakening of the Symbolic Dimension}

The military censorship of the creative expression of the prisoners in Buru, both on the stage and in the workplace, was very strict. Sometimes excuses for censorship were concocted as a means of demonstrating authority and passing judgment on that basis. Once the actor and director Basuki Effendi, whose film Si Pincang won an international award at a Prague Film Festival in the early 1960s, was physically tortured ("altered" was the prisoners' term, from the Dutch "vermaakt") after being caught singing "Come Back to Sorrento." The fact that he had chosen a song with the words "Come back" in it was taken to be a reference to the "comeback" of the PKI ("meng-kambek-kan PKI"). "What's this about come back?" ("Apa itu kambek-kambekkan, hah!?") shouted the unit commandant First Lieutenant Sukimo, punching Basuki like a boxer practicing on a punching bag. Lie Bok Hoo was "fanned" (slapped repeatedly about the head), following an accusation that he was giving a signal for a breakout by singing a "Malay rhythm" (dangdut) song that contained the words "Run, my horse, run!" Sudarno As was "rolled" (again referring to physical torture that finally "rolled" the prisoner over) for supposedly producing a wayang purwa gunungan that pitted the Army's Siliwangi Division against the PDI (Indonesian Democratic Party). As is well known, various figures are represented in the design of the gunungan, among them a buffalo and a tiger standing face to face. In the eyes of the unit authorities, this standard, traditional representation was intended, in this case, to portray the West Java Siliwangi Military Command (whose symbol happened to be a tiger) and the Indonesian Democratic Party (which uses the buffalo head as its symbol) both ready to attack each other. In another case, Sawal suffered a broken rib after being tortured for making seven garden plots in front of the commandant's house. He himself was unaware of any significance in the number seven, but it was interpreted as a symbol of the graves of the "Seven Heroes of the Revolution," the six generals and one junior officer who were the first victims of the events of the morning of October 1, 1965.

There were many other examples of attacks on symbols with left wing, and especially Communist, connotations, such as bans on the use of certain words like "comrade" (kawan), "brother" (bung), "the people" (rakyat), "banner" (panji), "hammer" (palu), "sickle" (arit), and "marhaen," the Sukarnoist term for the Indonesian "little man." Also forbidden was any representation of a buffalo head (the symbol of Sukarno's nationalist party, the PNI), the color red, the number three (because it was associated with the PKI's "three banners of development"), and all sorts of other things.

Even more absurd was the ban on the use of the words "pain" and "cold," to express these concepts. There were many cases of incidents related to "pain" and "cold" around 1971-1973. A prisoner complaining of stomach pain would go to the hospital, intending to 
get some medicine. He would be received by the health officer, often represented in fact by the agricultural officer or the deputy commandant of the unit. This officer would then order the prisoner to stand up. He would then batter the prisoner's stomach with his fist, thundering with each blow: "Where does it hurt?" "Here?" "Or here?" "Does it still hurt?" That cheap and effective form of medicine would only be withdrawn once the prisoner declared himself cured and answered: "Enough, sir, enough! It's all right, it's all right, it doesn't hurt any more!" And once he had that answer, of course, the officer couldn't be accused of lacking a humane and Pancasila spirit for ordering the prisoner to run straight back to his place of work.

Other prisoners went to the hospital complaining of the cold, because they were suffering malarial fever. In this case the cheap medicine handed out by the health officer was an even more effective version of the simalakama fruit known in Malay folklore. In the Malay story, if you eat the simalakama fruit it causes the death of your father; if you don't eat it, your mother dies. In the case of the Buru humanitarian project (reality in this case, not folklore) whatever you chose you would die. This was because the simalakama fruit in this case was an order to run around the assembly yard. Rather than be beaten for disobeying an order, the prisoner would choose to obey. He would run, and keep on running until he fell and fainted. (One of the victims of this "treatment" was Drs Dilar Darmawan, a graduate of the Faculty of Arts and Education at Gadjah Mada University in Yogyakarta, and a lecturer at the Saraswati University in Surakarta, which later had its name changed to the Eleventh of March University under the New Order.) The only other choice was to stop running and capitulate: report to the officer waiting at the side of the yard, and looking as though nothing was wrong declare that the fever had passed. The health officer, the inventor of this brilliant anti-malarial treatment, would respond with his other skill, his facility with words: 'Typical PKI, liar, loafer, you Abunawas! Get back to work! Even a buffalo has to work if it wants to eat!"

"Abunawas": In the Javanese "thousand and one nights," the figure of Abunawas, the faithful retainer of Sultan Harun Alrasyid, is a symbol of the cleverness and resourcefulness of the common people. But here, on Buru, at the hands of those in power who claimed to know everything, to be most "pancasilaist" and authoritative, Abunawas became a name for a liar and a loafer. But maybe they weren't all that mistaken, identifying him with these prisoners who bore the mark of "Communist."

In prison life on Buru symbols seemed to lose all their meaning. Values and meanings developed with such intensity, and concepts from the outside world were blocked and excluded, so the elaborate system of bans and prohibitions instituted by the military authorities really appeared excessive and unnecessary. Take the word "kawan," for example. It had once carried the ideological connotations of "comrade in arms," but this had been lost, and its original Malay meaning of "group" or "allies" also didn't apply any more. All it was was a synonym for "teman," meaning "friend," but even so, its use was forbidden.

In the early 1960s, I visited China with an Indonesian poet I will call Wisnu. In one place we were given a very enthusiastic welcome by some pioneer brigade girls wearing red ribbons. On the basis of that experience, Wisnu composed a short but effective poem called "Girls with Red Ribbons." It was a fresh and tuneful poem, which at the same time portrayed the aspirations for a youthful socialism. Once on Buru I went to see a friend who had been killed by a blow from a falling log. His head had been split open and his brain exposed. The color and smell of blood and brains are always the same in our sense of sight and smell. But the message on this occasion was different. My initial impression was not of 
emotion, but only the recollection of an incident from a wayang story, the death of the two giants Mahesa and Jatha Sura in the cave of Kiskendha in the Ramayana epic.

"Am I losing my mind?" I asked a friend. "Why am I not moved by this?"

"What does it mean to be moved?" The question came from Bayu, a prisoner from Unit IV Savanajaya, the eldest son of the pioneer of modern Indonesian art, S. Sudjojono and his wife Mia Bustam.

"If you were painting a picture of this, and you wanted it to be as naturalistic as possible, would red as you once knew it be enough to reproduce what you see here?" I asked him.

I didn't hear his reply. Maybe he was busy looking for another word for "red" to describe the redness of blood and the putrid smell of a smashed brain?

In front of the administration building or the guard post, the prisoners could see their fellow prisoners being tortured. Many times every day. They would watch from a distance, just watch, without the will or the ability to do anything about it. And if the incidence of torture appeared to decline, or especially if there was none at all, the prisoners would comment from behind their barracks' doors: "What's up? Quiet today, isn't it?"

Isn't this an indication that the word "torture" had begun to lose its meaning for the prisoners? There is even an old saying that goes: "hilang bisa karena biasa" - "the poison is lost with familiarity." So as long as "torture" remained within the limits of the prisoners' endurance, it wasn't torture at all, but a kind of "counterpoint" in the music of their daily lives.

Finally, a question: Isn't all of this an indication that the political prisoners were required to overturn the relationship between signifier and signified? Supposing that the penal colony of Buru hadn't come to an "early" end, would we have seen the emergence of an "abstractionist" literature as part of their self-expression?

\section{A Few Works of Art and Entertainment from Buru}

There is an old saying, "Fish in an aquarium can't see themselves." This may help explain why among so many writers, journalists, playwrights, and script writers who were prisoners on Buru, only a couple ever managed to write. (Among the writers in the Buru penal colony were Pramoedya Ananta Toer, Waluyadi Toer, Boejoeng Saleh, Hr. Bandaharo, Rivai Apin, S. Anantaguna, Samandjaja [Oei Haidjoen], Nusananta, Benny Tjhung, JT. Rahma, Amarzan Ismail Hamid, Sutikno WS, Timbul Darminto [all writers of literature], M. Naibaho, Hasjim Rahman, Tom Anwar, Habib Azhari, Sumartono Mertolojo, Hariyudi, Samodra and Kadi [journalists], Basuki Effendi, Bachtiar Siagian [scriptwriters/dramatists], Shamsuddin [writer of ludruk plays], and Badawi [ketoprak stage manager and actor].) Among that "couple" who did write were, in order of productivity:

Pramoedya Ananta Toer, who was segregated from other prisoners from 1973/74, with the job of "writing." That is why we find at the end of his novel Bumi Manusia [This Earth of Mankind] the note "Buru, Oral 1973, Written 1975." The "Written 1975" was the result of the change in his circumstances after 1973. But it should be known that before he wrote this novel, Pramoedya had already written (at least) two works in the form of scripts. The first was for a story in comic form called "Oroh," an historical fiction about Indonesia from the time of Trinil Man, when the ancestors of the Indonesian people spoke in sounds no more than two syllables at a time, till the coming of Mahayana and Hinayana Buddhism. The 
second was a play script called "Ki Ageng Mangir," the story of the defeat of Mangir, the last village republic in Java in the sixteenth century by Senapati, the founder of the second Mataram dynasty. In addition, he also began to collect material (from his own memories and the recollections of fellow prisoners) for a planned cultural encyclopaedia of Indonesia. All of this material he typed up on whatever bits of old paper he could find, including old cement bags. I think all of these manuscripts formed some kind of "umbrella" for his political novels about the rise of Indonesian nationalism; on the other hand, they provided him with material for the reports he had to make every Saturday of the "writing job" imposed on him by the camp commandant.

The second important name is Amarzan Ismail Hamid, who during his time in Buru never took up the hoe and faced the fields, but rather took up the pencil and faced the typewriter in the office of Unit XVI. There he produced "commissioned" stage plays to commemorate religious holidays, especially the Christian festivals celebrated by Catholics and Protestants. A poem entitled "Star of Bethlehem," which he wrote for stage performance was later set to choral music by Subronto Kusumo Atmodjo. It was first performed at Christmas 1974 in Unit XVI in Buru, and was later published by Gunung Mulia in Jakarta (1979), with additional narration by Julius Sijaranamual, a short story writer who, I understand, is the son of the ' 45 Generation Ambonese poet of the same name, who often published in Siasat at the end of the 1940s. That this composition was well received by the Indonesian Council of Churches in Jakarta is indicated in the gift of a typewriter which the Council made to Amarzan in 1976.

The writer Hr. Bandaharo was given the job of "mosque attendant" in his unit, partly in recognition of his age and the state of his health, but also of his knowledge of Islam. (He had once been a teacher in a Muhammadiyah secondary school in Medan.) One of his poems dated 1975 (when he was a resident of Unit XVIII in Buru) entitled Aku Hadir Di Hari Ini was included in his collection Sepuluh Sanjak Berkisah (Ten Narrative Poems), published by SKBSI/ World Citizen Press in Amsterdam in 1987/89. It was originally published in his collection Dosa Apa (What Sin?) published in Jakarta by Inkultra in 1981 and consisting of twelve long poems reflecting on the "period of disaster" he had experienced between 1965 and 1978.

As mentioned above, Boejoeng Saleh (Saleh Iskandar Poeradisastra) produced a version of the Pranacitra-Rara Mendut folktale (Jiku Kecil 1971), and wrote the English-language "Under the Firing Squad" (Unit XV, 1973) while working as caretaker of the barracks and the poultry pens, a job he was given for the same reasons that Hr. Bandaharo became mosque attendant. Samandjaja translated a manual on acupuncture and Plato's classic Republic, from an English pocketbook edition. (Unit XV, approx.1976-78). S. Anantaguna wrote a long article (handwritten in three exercise books) about Indonesian national culture (Unit XV, 1978). Nusananta (the pen name of Harsono Setiadi), inspired by Pramoedya's Bumi Manusia, began a novel about workers on a sugar plantation in East Java (Unit III, 1976-78). (The novel remained unfinished when Nusananta died in Yogya in 1983.) Rivai Apin composed a set of memoirs (unfinished) about important occurrences in his unit (Jiku Kecil, 1971-73) and a couple of poems (Ancol Unit, 1974-79). Kadi, while working in the kitchen of his barracks, wrote a collection of notes about life in Unit II, which he supplemented with a range of reliable data, in particular about an incident in 1978, when fifty prisoners escaped from the unit. Rachmat, while working as a supervisor of his barracks' gardens in 1976 wrote a set of notes about events in Unit V as a continuation of events surrounding the murder of Sergeant Umar in 1973. Budi Megaranta (Kho Djie Tjhay), defying the prohibitions, went from one barracks to another after the afternoon roll call, telling the stories Sam Kok or The Tale of Three Kingdoms (Unit XIV, 1972-73). Bachtiar 
Siagian, while a prisoner on the island of Nusa Kambangan in Central Java, composed a number of keroncong songs and an exposition on dramatic art (Unit R, 1977). Shamsuddin, a producer from the Ludruk Marhaen troupe in Surabaya, rewrote a ludruk play regarded as the most important basic text, "Sakerah" (Unit R, 1977/78), and produced a paper on the history of ludruk which was also unfinished on his death about eighteen months after he was returned to Java.

In a functional sense the border between art and entertainment is nothing more than a smoke screen, in the sense that they both are able to "entertain" or "delight the senses." If there is a difference between them, the difference lies in the quality of their content, which in turn results in differences in the way of conveying that content. Meanwhile the question of the quality of the content is itself closely related to (if not determined absolutely by) the question of "from whom and for whom" the content is expressed. Lay people (in the context of political prisoners this was the "masses") whose cultural outlooks are not influenced by the tastes of urban people make fun of music of the "lieder" type, for example, because to them it sounds like the howling of cats mating. On the other hand, those of "priyayi" cultural tastes (in this context the "cadres") made fun of the "dangdut" music styles, which to them evoked the world of the urban fringe dwellers and were of much lower status than keroncong. While they would see the movements of folk theater performances like lenong as shallow and crude, the kampung people would see the classical court dancers as hallucinatory indulgences, parodying the term "adiluhung" ("superior refinment") usually used to describe court art as "adi linglung" ("super dopey"). (I am indebted to Nancy Florida and Halim Hd. for this information.) As such, if the "entertainment" repertoire can be placed on the same level as the "art" repertoire, the "entertainer" can come to feel as respected as the "artist."

This in my understanding was what characterized the position of art/entertainment in the life of prisoners in Unit XIV Bantalareja, which I think should be taken as exemplary. This unit was known as the "pure Jakarta unit," because the 500 prisoners it contained were all from the two big Jakarta camps, Salemba and Tangerang. Their ages ranged from 20 to 60 , with the majority being between 25 and 35 in 1971. Their educational levels ranged from primary school (the majority) to university (there were three graduates), and they were from Betawi, Sundanese, and (Central) Javanese speaking communities. Compared to the other units, they had the most complete entertainment/arts groups, so it wasn't surprising if the "basic capital" for the camp command band was drawn from this unit as well. They had an "orkes Melayu" named Sinar Bantala, a keroncong group called Irama Bantala, under the direction of Go Giok Liong, a violinist from the Studio Jakarta kroncong orchestra of Jakarta in the 1950s. The band or orchestral group Bantala Nada was under the direction of David Martin Lampanguli and Basuki Effendi (later Samsu Bachri, after the first two were transferred to the camp command band). They had two theater groups, a ketoprak/wayang orang troupe Krida Bantala directed by Mohidi/Warna Wamin, and a lenong troupe directed by Tahir Yahya, a former member of the national council of the trade union federation SOBSI and husband of the Gerwani leader Sri Ambar.

Between about 1971 and 1975, theatrical activities really did represent forced labor for the prisoners, because they were held entirely for the benefit of the camp commandant and his staff, and the guards. In 1973, under Captain Yusin Zainal, the "theater" was in fact turned into an isolation barracks to house prisoners who had infringed serious prohibitions. But from 1975, almost every Saturday night, on their own initiative (and of course with the permission of the unit command) the artists and entertainers would conduct rehearsals in gamelan playing and other forms of music, which led on average to a full performance once 
every three months. They must have produced dozens of ketoprak and lenong performances, which all contained recitation of tembang or pantun. But aside from the tendency of folk art toward improvised performance (with nothing written down apart from a summary required by the authorities for censorship purposes), it was not their practice to create new play scripts, because that would have invited the suspicion of the censors. At most, the plays they performed were only "political prisoner versions" of already existing plays. The same was the case with the pantun they sang, though they would include topical references to aspects of life in Buru, like kacang buncis, the beans grown only in the officers' gardens, tetreks, the synthetic material only prisoners with money could afford, and kayu meranti, the timber which was one of the island's main forestry products. These references would be made sarcastically, and in the exchange of pantun would require some suitable reply, something that showed the existence of creative ability, even though only at the level of word play, to avoid the notice of the authorities.

\section{Commissioned Works}

However bad conditions were, the artists and entertainers in the units managed to maintain their independence. This wasn't the case, however, with the artists and craftsmen who were grouped around the command headquarters, except the writers (in this case Pramoedya) who worked with language, and were able to "play with two books," one for the authorities to examine and one for their own use. Tristuti Rachmadi did compose a wayang lakon, but it was written for the 1977 general election campaign, and was entitled "Revelation of the Golden Banyan Tree," referring to the symbol employed by the government's political organization, Golkar. Tristuti and his group once performed wayang kulit entirely in Indonesian, apart from the suluk songs, but this experiment was never repeated.

Like the woodcarvers, the painters were kept busy with commissions: portraits of soldiers or their families, or the legend of Jaka Tarub and the Seven Nymphs. Nevertheless Permadi Lyosta did manage to "really paint." The same was true of the musician Subronto Kusumo Atmodjo, who not only busied himself with arrangements (if "arrangements" are not regarded as "creativity") and made an original creative work of the commissioned Christmas cantata "Star of Bethlehem," but also wrote a Serenade for Violin and Cello called "From the Jungles of Waitina," an instrumental composition inspired by the jungle behind the location of his unit.

\section{Conclusion}

In world literature we are familiar with what is called "the literature of exile." The discussion above is intended as a report on a variant form of the literature of exile. I have attempted to draw attention to three things: first, that in Buru between the years of 1969 and 1979 there existed an "Indonesian art of exile within Indonesia itself"; second, that Pramoedya Ananta Toer as the towering figure in the art of exile in Buru was actually surrounded by many other figures of note; and third, that though these other figures may not stand as tall or as great, they are as firm and upright as the major one.

Furthermore, if this discussion of the art and literature of internal exile were to be extended to include that of external exile, there would be added the wealth of other figures like Basuki Resobowo, Agam Wispi, the Aidit brothers Sobron and Asahan, Supriadi, and a list of other names as well. These old names that have almost become foreign names "must be noted," must "receive their place," as Chairil Anwar said in his poem "Tjatetan th. 1946." And it needs to be done now! Why not? Isn't the art and literature of a nation the biography of that nation? Wasn't what later came to be known as "Balinese-Javanese literature" origi- 


\section{Hersri}

nally a form of Javanese literature in exile? So too "Indonesian" culture needs to embrace the art and literature of the exiles of Buru, and their fellow exiles abroad. They too have contributed to the "biography" of our nation. 